\title{
Pengaruh Kinerja Keuangan terhadap Harga SahamPerusahaan- Perusahaan Produsen Kabel yang Terdaftar di Bursa Efek Indonesia
}

\author{
Chinderayi Adha \\ Departemen Manajemen, Fakultas Ekonomi dan Manajemen \\ Institut Pertanian Bogor \\ Kampus Darmaga Bogor 16680 \\ Farida Ratna Dewi \\ Departemen Manajemen, Fakultas Ekonomi dan Manajemen \\ Institut Pertanian Bogor \\ Kampus Darmaga Bogor 16680 \\ e-mail: reidadewi@gmail.com
}

\begin{abstract}
Cable industries are industriesdealing with manufactures of cables and wires with aluminum, copper or others as their raw materials. The purposes of this study were: 1) to analyze the Net Profit Margin (NPM), Return On Investment (ROI), Return on Equity (ROE) and Earnings Per Share (EPS) from 2008 to 2012 of the cable manufacturer companies listed on the Indonesia Stock Exchange (IDX);2) to analyze the impacts of NPM, ROI, ROE, and EPS in 2008-2012 on the cable company's stock price in the IDX. The method used in this study was Structural Equation Modeling Partial Least Square (SEM-PLS). The results show that the values of the NPM outer loading original sample is $0.792, R O I$ is $0.873, R O E$ is 0.895 , and EPS is 0.905. Since high values mean that the indicators represent the construct and affect the stock prices, the indicator that has the most influence on stock prices was EPS. The results also reveals that the financial performance was able to explain share price for $44.4 \%$.

Keywords: BEI, cable, financial performance, stock
\end{abstract}

\begin{abstract}
ABSTRAK
Industri kabel merupakan industri yang bergerak di bidang pembuatan kabel dan kawat aluminium dan tembaga serta bahan baku lainnya, beserta seluruh komponen. Tujuan penelitian ini adalah : 1) Menganalisis Net Profit Margin (NPM), Return On Investment (ROI), Return on Equity (ROE), dan Earning Per Share (EPS) periode 2008-2012 pada perusahaan produsen kabel yang terdaftar di Bursa Efek Indonesia (BEI);2) Menganalisis pengaruh NPM, ROI, ROE, dan EPS periode 2008-2012 terhadap harga saham pada perusahaan kabeldi BEI Metode yang akan digunakan adalah Structural Equation Modeling Partial Least Square (SEM-PLS). Hasil penelitian menunjukkan nilai outer loading original sample NPM sebesar 0.792, ROI sebesar 0.873, ROE sebesar 0.895, dan EPS sebesar 0.905. Semakin tinggi nilainya berarti indikator tersebut semakin mewakili konstrak dan berpengaruh terhadap harga saham. Sehingga indikator paling berpengaruh terhadap harga saham adalah EPS. Hasil penelitian menunjukkan konstrak kinerja keuangan mampu menjelaskan harga saham sebesar $44.4 \%$.
\end{abstract}

Kata kunci: BEl, kabel , kinerja keuangan, saham

\section{Pendahuluan}

Produsen kabel yang terdaftar di Bursa Efek Indonesia (BEI) merupakan industri yang bergerak di bidang pembuatan kabel dan kawat aluminium dan tembaga serta 
bahan baku lainnya. Hal menarik dari industri kabel tersebut adalah konsumsi kabel yang terus bertambah di pasar domestik seiring dengan pembangunan di berbagai sektor baik yang dilakukan oleh pemerintah maupun swasta. Di Indonesia, konsumsi kabel berbahan tembaga dan aluminium terus mengalami peningkatan dari tahun 2010 hingga 2013 (Pefindo 2013).

Hal tersebut merupakan dampak dari program percepatan pembangunan pembangkit listrik dalam negeri $10000 \mathrm{MW}$ tahap I yang diperkirakan telah selesai pada tahun 2013, dan akan dilanjutkan dengan program percepatan pembangunan pembangkit listrik 10000 MW tahap II (Kementerian ESDM 2010). Program percepatan pembangunan pembangkit listrik $10000 \mathrm{MW}$ tersebut merupakan salah satu contoh utama dari rangkaian proyek infrastruktur yang tergabung dalam Masterplan Percepatan Perluasan Pembangunan Ekonomi Indonesia (MP3EI) dan akan selesai pada tahun 2020. Dengan adanya MP3El, penambahan kebutuhan energi listrik di Indonesia hingga tahun 2025 diproyeksikan mencapai $90000 \mathrm{MW}$ (dalam kondisi beban puncak). Dari jumlah tersebut, sebagian besar kebutuhan energi akan digunakan untuk mendukung pembangunan dan pengembangan kegiatan-kegiatan ekonomi utama di dalam koridor (Kemenko Perekonomian 2011).

Kinerja keuangan sebuah perusahaan dapat menunjukkan seberapa mampu sebuah perusahaan menghasilkan keuntungan dan memakmurkan para pemegang saham, termasuk di industri kabel. Hal ini akan dapat mempengaruhi harga saham di pasar atau bursa saham. Kinerja keuangan tercermin dalam rasio-rasio keuangan yang akan menunjukkan kemampuan perusahaan dalam hal likuiditas, efisiensi penggunaan aktiva, fungsi leverage, dan profitabilitas. Menurut Tambunan (2007), para analis sekuritas dan pemegang saham umumnya sangat memperhatikan rasio Return on Equity (ROE). Semakin tinggi ROE yang dihasilkan perusahaan, dapat mendorong semakin tinggi harga sahamnya. Menurut Bastian dan Suhardjono (2006), semakin besar Net Profit Margin (NPM), maka kinerja perusahaan akan semakin produktif, sehingga akan meningkatkan kepercayaan investor untuk menanamkan modalnya pada perusahaan tersebut.

Penelitian yang pernah dilakukan oleh Pirie dan Smith (2005), menjelaskan bahwa terdapat hubungan antara harga saham dan informasi akuntansi. Penelitian lain yang dilakukan oleh Karunarathne danRajapakse (2010) bahwa Earning Per Share (EPS) merupakan variabel yang paling relevan terkait dengan stock prices.

Berdasarkan pendapat dan hasil penelitian tersebut diatas, maka dalam penelitian ini difokuskan pada rasio profitabilitas dengan indikator-indikator yaitu $N P M$, Return On Investment (ROI), ROE, dan EPS. Adapun permasalahan yang akan dibahas dalam penelitian ini adalah : 1) Bagaimana kondisi rasio profitabilitas periode 2008-2012 pada perusahaan produsen kabel yang terdaftar di BEI?; 2) Bagaimana pengaruhindikator dalam rasio profitabilitas terhadap harga saham pada produsen kabeldi BEl?.

Tujuan penelitian ini adalah : 1) Menganalisisrasio profitabilitas periode 20082012 pada perusahaan produsen kabel yang terdaftar di BEI; 2) Menganalisis pengaruh indikator dalam rasio profitabilitas terhadap harga saham pada perusahaan kabeldi BEI. 


\section{Metode Penelitian}

Penelitian ini dimaksudkan untuk melihat pengaruh kinerja keuangan terhadap harga saham perusahaan-perusahaan produsen kabel yang terdaftar di BEI. Pengaruh hubungan kinerja keuangan terhadap harga saham ini dapat menjadi gambaran dan rekomendasi bagi calon investor serta pihak-pihak yang membutuhkan. Pengukuran rasio keuangan perusahaan merupakan salah satu indikator yang dipergunakan investor untuk menilai suatu perusahaan yang terekspresikan dalam harga pasar saham. Kerangka pemikiran dapat dilihat pada Gambar 1.

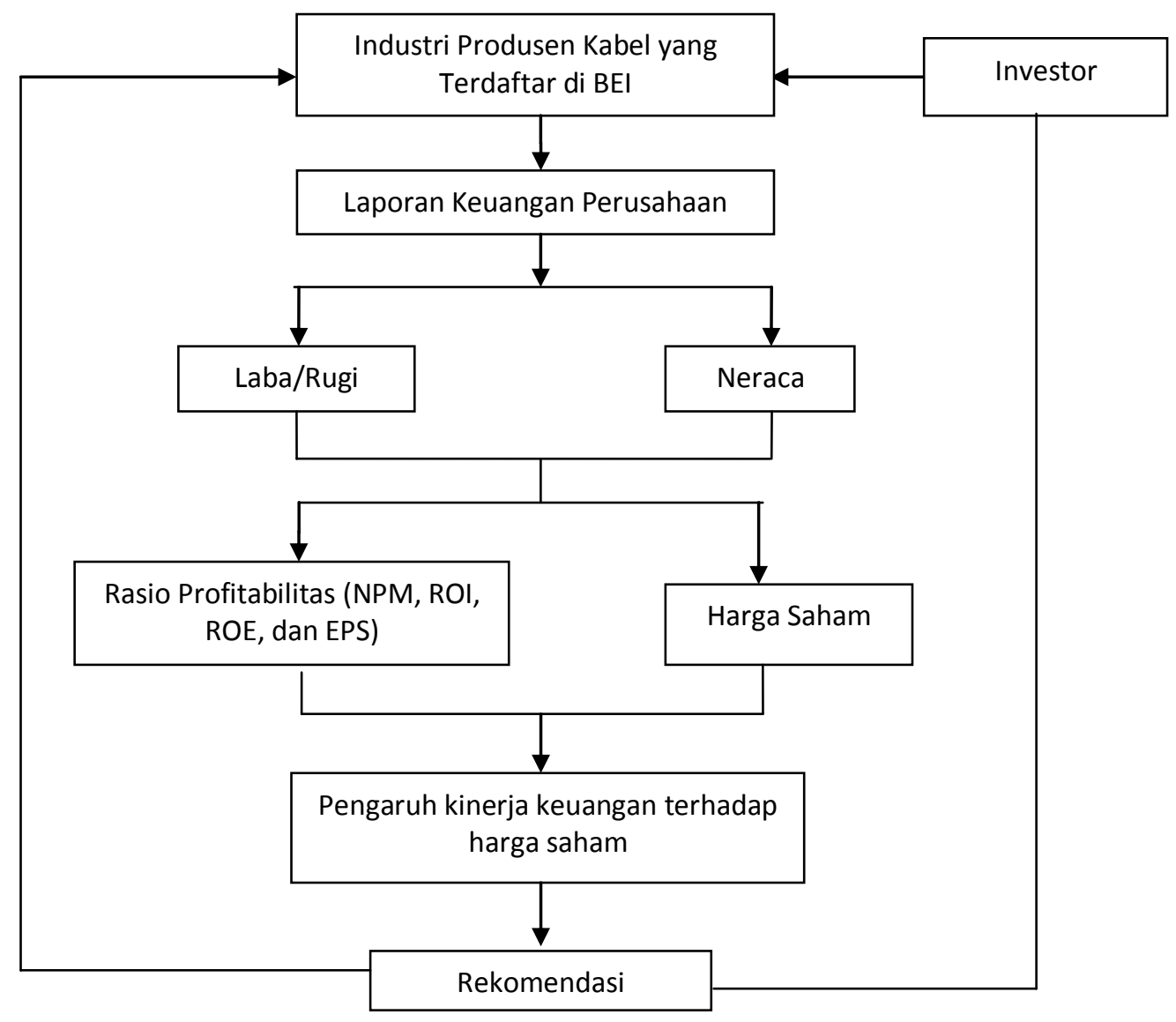

Gambar 1. Kerangka pemikiran konseptual

Penelitian ini dilaksanakan pada bulan Maret 2013 sampai dengan bulan Mei 2013 dan lokasi penelitian dilakukan di BEI (data sekunder). Jenis data yang digunakan dalam penelitian ini berupa data sekunder yang berasal dari data laporan tahunan (annual report) tahun 2008-2012 yang telah dipublikasi, serta laporan keuangan triwulan tahun 2012. Laporan keuangan dan laporan tahunan diunduh dari website resmi milik BEI. Populasi perusahaan produsen kabel yang terdaftar di BEI berjumlah enam perusahaan, sehingga penelitian ini menggunakan seluruh populasi yang ada. Adapun populasi tersebut meliputi PT KMI Wire and Cable Tbk, PT Jembo Cable Company Tbk, PT Kabelindo Murni Tbk, PT Sucaco Tbk, PT Sumi Indo Kabel Tbk, dan PT Voksel Electric Tbk. 
Bentuk pengaruh antara kinerja keuangan dan harga saham dapat dijelaskan menggunakan salah satu metode alternatif Structural Equation Modelling (SEM) Partial Least Square (PLS). PLS merupakan metode alternatif dengan pendekatan berbasis varians atau komponen yang berorientasi pada prediksi model. Menurut Yamin dan Kurniawan (2009), evaluasi model dalam PLS meliputievaluasi outer model danevaluasi inner model. Pengukuran variabel berupa variabel rasio keuangan terdiri atas NPM, ROI, ROE, dan EPS (Samryn 2001).

Hipotesis-hipotesis penelitian ini adalah sebagai berikut:

1. H10 : NPM tidak berpengaruh positif terhadap harga saham

2. H11 : NPM berpengaruh positif terhadap harga saham

3. H2O : ROI tidak berpengaruh positif terhadap harga saham

4. $\mathrm{H} 21$ : ROI berpengaruh positif terhadap harga saham

5. H30 : ROE tidak berpengaruh positif terhadap harga saham

6. H31 : ROE berpengaruh positif terhadap harga saham

7. H40 : EPS tidak berpengaruh positif terhadap harga saham

8. H41 : EPS berpengaruh positif terhadap harga saham

\section{Hasil dan Pembahasan}

III.1. Kinerja Keuangan

1. NPM

NPM merupakan rasio antara laba bersih dan penjualan bersih. NPM industri kabel yang terdaftar di BEl dapat dilihat pada Tabel 1.

Tabel 1. NPM industri kabel yang terdaftar di BEI 2008-2012

\begin{tabular}{llcccccc}
\hline No & \multicolumn{1}{c}{ Nama Perusahaan } & $\begin{array}{c}\mathbf{2 0 0 8} \\
\mathbf{( \% )}\end{array}$ & $\begin{array}{c}\mathbf{2 0 0 9} \\
\mathbf{( \% )}\end{array}$ & $\begin{array}{c}\mathbf{2 0 1 0} \\
\mathbf{( \% )}\end{array}$ & $\begin{array}{c}\mathbf{2 0 1 1} \\
\mathbf{( \% )}\end{array}$ & $\begin{array}{c}\mathbf{2 0 1 2} \\
\text { (\%) }\end{array}$ & $\begin{array}{c}\text { Rata-Rata } \\
\text { (\%) }\end{array}$ \\
\hline 1 & PT Jembo Cable Company Tbk & 0.01 & 2.07 & -0.12 & 2.34 & 257 & 1.37 \\
2 & PT Kabelindo Murni Tbk & 0.74 & 0.56 & 0.72 & 2.19 & 2.30 & 1.30 \\
3 & PT KMI Wire and Cable Tbk & 1.54 & 2.52 & 3.93 & 3.46 & 5.51 & 3.39 \\
4 & PT Sucaco Tbk & 1.21 & 2.77 & 2.76 & 3.28 & 4.78 & 2.96 \\
5 & PT Sumi Indo Kabel Tbk & 5.94 & 3.33 & 0.38 & 0.93 & 3.25 & 2.76 \\
6 & PT Voksel Electric Tbk & 0.23 & 3.10 & 0.78 & 5.49 & 5.90 & 3.10 \\
\hline
\end{tabular}

Sumber: Laporan Tahunan dan Laporan Keuangan masing-masing perusahaan tahun 2011 dan 2012 (diolah)

Peningkatan NPM yang signifikan disebabkan oleh kenaikan persentase laba bersih yang melebihi peningkatan penjualan bersih. Sedangkan penurunan NPM yang signifikan disebabkan oleh persentase penurunan laba yang jauh melebihi penurunan penjualan. Nilai NPM rata-rata tertinggi dari tahun 2008-2012 terjadi pada PT KMI Wire and Cable Tbk.

2. ROI

ROI merupakan rasio antara laba bersih setelah pajak dan total aktiva atau aset. ROI industri kabel yang terdaftar di BEl dapat dilihat pada Tabel 2. 
Tabel 2. ROI industri kabel yang terdaftar di BEI 2008-2012

\begin{tabular}{llcccccc}
\hline No & \multicolumn{1}{c}{$\begin{array}{c}\text { Nama Perusahaan } \\
\end{array}$} & $\begin{array}{c}\mathbf{2 0 0 8} \\
\mathbf{( \% )}\end{array}$ & $\begin{array}{c}\mathbf{2 0 0 9} \\
\mathbf{( \% )}\end{array}$ & $\begin{array}{c}\mathbf{2 0 1 0} \\
\mathbf{( \% )}\end{array}$ & $\begin{array}{c}\mathbf{2 0 1 1} \\
\mathbf{( \% )}\end{array}$ & $\begin{array}{c}\mathbf{2 0 1 2} \\
\mathbf{( \% )}\end{array}$ & $\begin{array}{c}\text { Rata-Rata } \\
\text { (\%) }\end{array}$ \\
\hline 1 & PT Jembo Cable Company Tbk & 0.01 & 2.69 & -0.18 & 4.74 & 4.48 & 2.35 \\
2 & PT Kabelindo Murni Tbk & 0.87 & 0.48 & 0.96 & 2.96 & 3.30 & 1.71 \\
3 & PT KMI Wire and Cable Tbk & 4.39 & 4.22 & 5.04 & 5.88 & 10.78 & 6.06 \\
4 & PT Sucaco Tbk & 0.94 & 1.75 & 5.25 & 7.53 & 11.40 & 5.37 \\
5 & PT Sumi Indo Kabel Tbk & 15.35 & 5.11 & 0.77 & 2.10 & 6.79 & 6.02 \\
6 & PT Voksel Electric Tbk & 0.45 & 4.33 & 0.91 & 7.03 & 8.70 & 4.28 \\
\hline
\end{tabular}

Sumber: Laporan tahunan dan laporan keuangan masing-masing perusahaan tahun 2011 dan 2012 (diolah)

Peningkatan ROI yang signifikan disebabkan oleh kenaikan laba bersih yang melebihi peningkatan total aktiva. Sedangkan penurunan NPM yang signifikan, disebabkan oleh penurunan laba yang jauh melebihi penurunan total aktiva. Nilai ROI rata-rata tertinggi dari tahun 2008-2012 dimiliki oleh PT KMI Wire and Cable Tbk.

3. ROE

ROE merupakan rasio antara laba bersih setelah pajak dan total ekuitas. ROE industri kabel yang terdaftar di BEI dapat dilihat pada Tabel 3.

Tabel 3. ROE industri kabel yang terdaftar di BEI 2008-2012

\begin{tabular}{clcccccc}
\hline No & Nama Perusahaan & $\begin{array}{c}\mathbf{2 0 0 8} \\
\mathbf{( \% )}\end{array}$ & $\begin{array}{c}\mathbf{2 0 0 9} \\
\mathbf{( \% )}\end{array}$ & $\begin{array}{c}\mathbf{2 0 1 0} \\
\mathbf{( \% )}\end{array}$ & $\begin{array}{c}\mathbf{2 0 1 1} \\
\mathbf{( \% )}\end{array}$ & $\begin{array}{c}\mathbf{2 0 1 2} \\
\mathbf{( \% )}\end{array}$ & $\begin{array}{c}\text { Rata-Rata } \\
\text { (\%) }\end{array}$ \\
\hline 1 & PT Jembo Cable Company Tbk. & 0.09 & 15.42 & -1.01 & 23.31 & 22.24 & 12.01 \\
2 & PT Kabelindo Murni Tbk. & 1.77 & 0.76 & 1.39 & 7.78 & 9.00 & 4.14 \\
3 & PT KMI Wire and Cable Tbk. & 12.80 & 9.02 & 7.36 & 8.85 & 14.81 & 10.57 \\
4 & PT Sucaco Tbk. & 2.95 & 4.81 & 14.31 & 21.28 & 26.09 & 13.89 \\
5 & PT Sumi Indo Kabel Tbk. & 19.26 & 5.84 & 0.93 & 2.56 & 9.11 & 7.54 \\
6 & PT Voksel Electric Tbk. & 1.66 & 14.27 & 2.66 & 22.27 & 24.40 & 13.05 \\
\hline
\end{tabular}

Sumber: Laporan tahunan dan laporan keuangan masing-masing perusahaan tahun 2011 dan 2012 (diolah)

Peningkatan ROE yang signifikan, disebabkan oleh kenaikan laba bersih yang melebihi peningkatan total ekuitas. Sedangkan penurunan ROE yang signifikan disebabkan oleh penurunan laba yang jauh melebihi penurunan total ekuitas. Nilai ROE rata-rata tertinggi dari tahun 2008 hingga 2012 dimiliki oleh PT Sucaco Tbk.

\section{EPS}

EPS merupakan rasio antara laba bersih setelah pajak dan jumlah saham biasa. EPS industri kabel yang terdaftar di BEI dapat dilihat pada Tabel 4.EPS industri kabel sebagimana pada Tabel 4 cenderung fluktuatif. Peningkatan EPS yang signifikan disebabkan oleh kenaikan laba bersih yang dialami perseroan. Sedangkan penurunan EPS yang signifikan disebabkan oleh penurunan laba yang dialami perseroan. Namun dapat dilihat bahwa seluruh perusahaan kabel mengalami kenaikan EPS dari tahun 2011 sampai 2012. Peningkatan ini disebabkan oleh penurunan harga alumunium dan tembaga yang merupakan bahan baku untuk industri kabel. Nilai rata-rata EPS tertinggi dari tahun 2008 hingga tahun 2012 dimiliki oleh PT Sucaco Tbk. 
Tabel 4. EPS industri kabel yang terdaftar di BEI 2008-2012 (dalam Rupiah)

\begin{tabular}{llcccccc} 
No & Nama Perusahaan & $\begin{array}{c}\mathbf{2 0 0 8} \\
\mathbf{( \% )}\end{array}$ & $\begin{array}{c}\mathbf{2 0 0 9} \\
\mathbf{( \% )}\end{array}$ & $\begin{array}{c}\mathbf{2 0 1 0} \\
\mathbf{( \% )}\end{array}$ & $\begin{array}{c}\mathbf{2 0 1 1} \\
\mathbf{( \% )}\end{array}$ & $\begin{array}{c}\mathbf{2 0 1 2} \\
\mathbf{( \% )}\end{array}$ & $\begin{array}{c}\text { Rata- } \\
\text { Rata (\%) }\end{array}$ \\
\hline 1 & PT Jembo Cable Company & 0.53 & 104.50 & -6.61 & 196.43 & 211.71 & 101.31 \\
2 & PT Kabelindo Murni Tbk. & 3.56 & 1.51 & 3.47 & 16.97 & 21.28 & 9.36 \\
3 & PT KMI Wire and Cable & 6.54 & 5.17 & 12.06 & 15.89 & 31.24 & 14.18 \\
4 & PT Sucaco Tbk. & 55.00 & 88.73 & 295.57 & 532.98 & 824.43 & 359.34 \\
5 & PT Sumi Indo Kabel Tbk. & 319.24 & 93.85 & 15.03 & 42.00 & 173.24 & 128.67 \\
6 & PT Voksel Electric Tbk. & 6.30 & 64.45 & 12.35 & 133.10 & 176.74 & 78.59 \\
\hline
\end{tabular}

Sumber: Laporan tahunan dan laporan keuangan masing-masing perusahaan tahun 2011 dan 2012 (diolah)

\section{III.2. Harga Saham}

Harga saham yang dipakai pada penelitian ini merupakan rata-rata satu tahun data harga penutupan (closing) saham harian industri kabel yang terdaftar di BEI dari tahun 2008-2012. Harga saham rata-rata industri kabel yang terdaftar di BEI 20082012 dapat dilihat pada Tabel 5.

Tabel 5. Harga saham harian rata-rata satu tahun 2008-2012 (dalam rupiah)

\begin{tabular}{|c|c|c|c|c|c|c|c|}
\hline No & Nama Perusahaan & $\begin{array}{c}2008 \\
(\%)\end{array}$ & $\begin{array}{c}2009 \\
(\%)\end{array}$ & $\begin{array}{c}2010 \\
(\%)\end{array}$ & $\begin{array}{c}2011 \\
(\%)\end{array}$ & $\begin{array}{c}2012 \\
(\%)\end{array}$ & $\begin{array}{c}\text { Rata- } \\
\text { Rata } \\
\text { (\%) }\end{array}$ \\
\hline 1 & PT Jembo Cable Company Tbk & 405.2 & 379.3 & 603.9 & 548.7 & 1693.0 & 726.0 \\
\hline 2 & PT Kabelindo Murni Tbk. & 96.9 & 114.5 & 124.7 & 110.1 & 134.2 & 116.1 \\
\hline 3 & PT KMI Wire and Cable Tbk. & 69,7 & 54.6 & 67.8 & 98.0 & 158.6 & 89.7 \\
\hline 4 & PT Sucaco Tbk. & 1257.0 & 1312.0 & 1620.7 & 2313.0 & 4090.3 & 2118.8 \\
\hline 5 & PT Sumi Indo Kabel Tbk. & 806.6 & 953.5 & 1331.8 & 1568.6 & 1278.7 & 1187.8 \\
\hline 6 & PT Volsel Electric Tbk. & 557.5 & 341.7 & 408.9 & 600.2 & 1107.9 & 603.2 \\
\hline
\end{tabular}

Sumber: Yahoo Inc (2012)

Harga saham perusahaan-perusahaan yang sudah go public cenderung naik turun, baik itu per tahun, per bulan, per minggu, maupun per hari. Tabel 5 memperlihatkan bahwa seluruh perusahaan kabel yang terdaftar di BEI sama-sama meningkat harga sahamnya dari tahun 2009 hingga 2010. Kemudian perusahaanperusahaan kabel terkecuali PT Sumi Indo Kabel Tbk memiliki nilai saham tertinggi pada tahun 2012. Sedangkan PT Sumi Indo Kabel Tbk saham tertinggi berada pada tahun 2011. Harga saham rata-rata tertinggi dari tahun 2008 hingga 2012 dimiliki oleh PT Sucaco Tbk.

\section{III.3. Pembahasan Model SEM-PLS}

\section{Model SEM-PLS}

Metode SEM-PLS dipergunakan untuk mencari seberapa besar pengaruh antar konstrak. Gambar lingkaran adalah konstrak dan persegi panjang adalah indikator.EPS, NPM, ROE, dan ROI merupakan indikator reflektif dari konstrak kinerja keuangan, artinya bahwa konstrak kinerja keuangan diwakili oleh indikator EPS, NPM, ROE, dan ROI. Model SEM-PLS untuk mencari pengaruh kinerja keuangan dengan harga saham perusahaan-perusahaan kabel yang terdaftar di BEI dapat dilihat pada Gambar 2. 


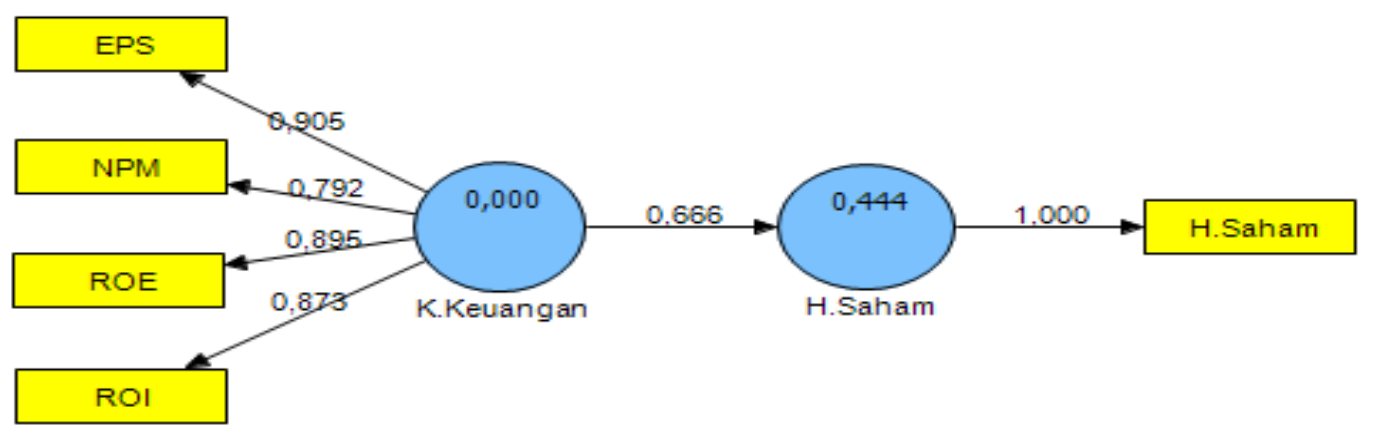

Gambar 1. Model SEM-PLS pengaruh kinerja keuangan terhadap harga saham

Berdasarkan hasil uji validitas dan realibilitas dengan hasil semua indikator memiliki loading factor di atas 0.55 sehingga dinyatakan valid dan memiliki nilai composite reliability konstrak harga saham sebesar 1.000 dan nilai composite reliability konstrak kinerja keuangan sebesar 0.924 sehingga dapat dinyatakan reliable.

2. Uji Hipotesis

Uji hipotesis yang dinyatakan dapat dilihat pada Path Coefficients yang terdapat pada Tabel 6.

Tabel 6. Path coefficients (mean, STDEV, t-values)

\begin{tabular}{lccccc}
\hline & $\begin{array}{c}\text { Original } \\
\text { Sample } \\
\text { (O) }\end{array}$ & $\begin{array}{c}\text { Sample Mean } \\
\text { (M) }\end{array}$ & $\begin{array}{c}\text { Standard } \\
\text { Deviation } \\
\text { (STDEV) }\end{array}$ & $\begin{array}{c}\text { Standard } \\
\text { Error } \\
\text { (STERR) }\end{array}$ & $\begin{array}{c}\text { T Statistics } \\
\text { (|O/STERR|) }\end{array}$ \\
\hline $\begin{array}{l}\text { K.Keuangan - } \\
>\text { H.Saham }\end{array}$ & 0.666436 & 0.662955 & 0.071109 & 0.071109 & 9.372101 \\
\hline
\end{tabular}

Sumber: Hasil pengolahan data SmartPLS 2.0

Tabel 6 menunjukkan bahwa hubungan antara konstrak kinerja keuangan dengan harga saham adalah signifikan dengan T-statistik melebihi 1.96. Nilai original sample estimate adalah positif yaitu sebesar 0.666436, yang menunjukkan bahwa arah hubungan antara kinerja keuangan dengan harga saham adalah positif. Seberapa besar masing-masing indikator dapat mewakili konstrak kinerja keuangan dapat dilihat pada Tabel 7.

Tabel 7. Outer loadings indikator kinerja keuangan

\begin{tabular}{lc}
\hline & Original Sample (O) \\
\hline EPS <- K.Keuangan & 0.905214 \\
NPM <- K.Keuangan & 0.792355 \\
ROE <- K.Keuangan & 0.894923 \\
ROI <- K.Keuangan & 0.873386 \\
\hline
\end{tabular}

Sumber: Hasil pengolahan data SmartPLS 2.0

Tabel 7 menunjukkan bahwa nilai outer loadings original sample EPS adalah yang tertinggi. Semakin tinggi nilai tersebut berarti indikator tersebut semakin mewakili konstrak. Dengan kata lain EPS adalah indikator yang paling mewakili dan berpengaruh 
terhadap konstrak kinerja keuangan.EPS menggambarkan besarnya keuntungan yang akan didapat investor per lembar sahamnya apabila investor tersebut berinvestasi di perusahaan, semakin tinggi EPS berarti dapat meningkatkan daya tarik investor untuk berinvestasi di perusahaan-perusahaan kabel. Hal ini sejalan dengan hasil penelitian yang dilakukan oleh Karunarathne dan Rajapakse (2008) yang melibatkan 100 perusahaan yang listing di Colombo Stock Exchange (CSE) dengan data dari tahun 2004-2008, bahwa variabel yang paling berpengaruh (paling relevan) terhadap harga saham adalah EPS. Indikator berikutnya adalah ROE, ROI dan yang terkecil adalah NPM.

ROE menggambarkan kemampuan perusahaan dalam mengelola modal dalam menghasilkan laba. Jika nilai ROE tinggi maka investor akan menilai bahwa perusahaan mampu menghasilkan laba yang tinggi dengan ekuitas yang dimilikinya, sehingga akan dapat memakmurkan para pemegang saham. Begitu juga dengan nilai ROI yang tinggi, yang berarti perusahaan mampu mengelola investasinya dengan baik, sehingga mendatangkan tingkat keuntungan yang tinggi yang harapannya dapat memberikan imbal hasil yang tinggi pula kepada para pemegang saham. NPM memiliki nilai outer terkecil, hal ini dimungkinkan karena investor cenderung lebih mempertimbangkan nilai EPS, ROE dan ROI dibandingkan dengan NPM, namun dalam hal ini tetap NPM dilihat oleh investor sebagai hal yang perlu diperhitungkan dalam menentukan investasi.

Secara keseluruhan bahwa EPS, ROE, ROI dan NPM mampu menjelaskan konstrak harga saham sebesar $44.4 \%$ sehingga masih terdapat faktor lain yang dapat mempengaruhi harga saham, misalnya faktor ekonomi negara, politik, kemajuan teknologi dan lainnya.Dengan demikian hipotesis H11 (NPM berpengaruh positif terhadap harga saham), H21 (ROI berpengaruh positif terhadap harga saham), H31 (ROE berpengaruh positif terhadap harga saham), dan H41 (EPS berpengaruh positif terhadap harga saham) dalam penelitian ini diterima sebab kinerja keuangan yang memiliki indikator NPM, ROI, ROE, dan EPS berpengaruh positif terhadap harga saham.

\section{Kesimpulan}

Nilai NPM, ROI, ROE, dan EPS periode 2008-2012 perusahaan-perusahaan produsen kabel yang terdaftar di BEI mengalami fluktuasi dari tahun 2008-2010, kemudian mengalami peningkatan pada tahun 2011 dan kembali mengalami peningkatan menjadi lebih besar pada tahun 2012. Peningkatan tersebut disebabkan oleh peningkatan laba bersih yang dimiliki perusahaan.

Kinerja keuangan industri kabel terdaftar di BEI periode 2008-2012 yang terdiri dari indikator valid yakni NPM, ROI, ROE, dan EPS, berpengaruh positif terhadap harga saham. Indikator yang berpengaruh paling besar terhadap harga saham adalah EPS.

\section{Daftar Pustaka}

Bastian I, Suhardjono. 2006. Akuntansi Perbankan. Edisi ke-1. Jakarta (ID) : Salemba Empat. 
Karunarathne WVAD, Rajapakse RMDAP. 2010. The Value Relevance Of Financial Statements' Information : With Special Reference to The Listed Companies in Colombo Stock Exchange. International Conference on Business \& Information [Internet]. [2010; University of Kelaniya, Sri Lanka]. Sri Lanka (LK): University of Kelaniya. hlm 1-20; [diunduh 2014 Feb 27]. Tersedia pada: http://www.kln.ac.lk/uokr/icbi_2010.html.

[Kemenko Perekonomian] Kementerian Koordinator Bidang Perekonomian. 2011. Masterplan Percepatan dan Perluasan Pembangunan Ekonomi Indonesia. Jakarta(ID): Kemenko Perekonomian.

[Kementerian ESDM] Kementerian Energi dan Sumber Daya Mineral. 2010. Tahun 2013 Program Percepatan Pembangunan Pembangkit Listrik 10.000 Mw tahap I Selesai [Internet]. [diunduh 2013 Mei 21]; [Edisi dan volume tidak diketahui]. Tersedia pada: http://www.esdm.go.id/berita/37-umum/3756-tahun-2013program-percepatan-pembangunan-pembangkit-listrik-10000-mw-tahap-iselesai.html.

Pefindo Equity \& Index Valuation Division. 2013. Equity Valuation PT KMI Wire Cable Tbk. Jakarta (ID): Pefindo.

Pirie S, Smith M. 2005. Relationship Between Stock Prices and Accounting Information: A Review of The Residual Income and Ohlson Models. Working papers/School of Accounting, Finance and Economics, Edith Cowan University [Internet]. Australia (AU): Edith Cowan University. hlm 1-18; [diunduh 2014 Feb 27]. Tersedia pada: https://www.ecu.edu.au /_data/assets/pdf_file/0017/40733/wp0508sp.pdf

PT Jembo Cable Company Tbk. 2011. Laporan Tahunan 2011 dan 2012 PT Jembo Cable Company Tbk. Jakarta (ID): Bursa Efek Indonesia.

PT Kabelindo Murni Tbk. 2011. Laporan Tahunan 2011 dan 2012 PT Kabelindo Murni Tbk. Jakarta (ID): Bursa Efek Indonesia.

PT KMI Wire and Cable Tbk. 2011. Laporan Tahunan 2011 dan 2012 PT KMI Wire and Cable Tbk. Jakarta (ID): Bursa Efek Indonesia.

PT Sucaco Tbk. 2011. Laporan Tahunan 2011 dan 2012 PT Sucaco Tbk. Jakarta (ID): Bursa Efek Indonesia.

PT Sumi Indo Kabel Tbk. 2011. Laporan Tahunan 2011 dan 2012 PT Sumi Indo Kabel Tbk. Jakarta (ID): Bursa Efek Indonesia.

PT Voksel Electric Tbk. 2011. Laporan Tahunan 2011 dan 2012 PT Voksel Electric Tbk. Jakarta (ID): Bursa Efek Indonesia.

Samryn. 2001. Akuntansi Manajerial : Suatu Pengantar. Jakarta (ID) : Raja Graffindo Persada.

Tambunan A. 2007. Menilai Harga Wajar Saham. Jakarta (ID): PT Grasindo.

Yahoo Inc. 2012. Historical Prices [Internet]. [diunduh 2013 Mei 15]; [Edisi dan volume tidak diketahui]. Tersedia pada: http://finance.yahoo.com.

Yamin S, Kurniawan H. 2009. Structural Equation Modelling : Belajar Lebih Mudah Teknik Analisis Data Kuesioner dengan Lisrel-PLS. Jakarta (ID) : Salemba Infotek. 